\title{
Anatomical characterization of the roots, leaves and culms of Guadua weberbaueri in different growing environments
}

\author{
Yasmin Alves Santos Rodrigues ${ }^{1}$, Sebastião Kennon Ferreira Santos ${ }^{1}$, Frederico Henrique da Silva \\ Costa ${ }^{1}$, João Bosco de Oliveira Junior ${ }^{1}$, Said Bezerra Barbosa ${ }^{2,3}$, Moisés Silveira Lobão ${ }^{1}$, \\ Berenice Kussumoto de Alcântara $\mathbb{\circledR}^{1 *}$
}

\footnotetext{
${ }^{1}$ Universidade Federal do Acre. Rodovia BR 364, Km 04 - Distrito Industrial, Rio Branco - AC, Brazil. 69920-900

${ }^{2}$ Fundação de Tecnologia do Estado do Acre. Distrito Industrial, Rio Branco - AC, Brazil. 69920-202

${ }^{3}$ In memoriam
}

\section{Original Article \\ *Corresponding author:} bereniceka@gmail.com

Keywords:

Bamboo

Amazon region

Vascular bundles

Palavras-chave:

Bambu

Amazônia

Feixes vasculares

Received in

2019/11/14

Accepted on

2020/05/07

Published in

2020/06/30

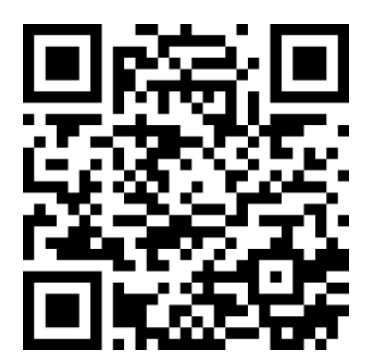

DOI:

https://doi.org/10.34062/afs. v7i2.9366

\section{(c) $\mathbf{B Y}$}

ABSTRACT: There has been increasing interest in the use of bamboo for a variety of purposes. In the western Amazon region, specifically in the state of Acre, Brazil, native bamboo (Guadua weberbaueri Pilg.) grows in great abundance, which calls attention to its possible sustainable exploitation. Bamboo anatomy is related to physical-mechanical characteristics, important properties related to bamboo uses. However, there is a lack of information in literature about anatomy of $G$. weberbaueri. Thus, this project aims to perform the anatomical characterization of the culms, leaves and roots of $G$. weberbaueri in two different environments that may influence anatomy, such as inside and along the border of a forest. For the analysis, samples were collected from culms, leaves and roots at the Zoobotanical Park of Federal University of Acre, and permanent slides were visualized by optical microscopy. We observed that the vascular bundles of the central leaf veins were wider in leaves from the border of the forest than in those from inside the forest. The study of root anatomy showed differences in the radius measurements of the xylem vessel elements, which were larger in those inside the forest than those from the border; however they were more frequent in the border than inside. The vascular bundles of culms did not present a difference, although a new characteristic found in this species is described (condensed fibers around the bundles) and it could be used for identification purposes. In general, we observed that the different environments can determine the sizes of conduction elements in roots and leaves, although we did not observe this influence in the G. weberbaueri culms.

\section{Caracterização anatômica de raízes, folhas e colmos de Guadua weberbauri em diferentes ambientes de crescimento}

RESUMO: Existe um grande interesse no uso do bambu para uma variedade de propósitos. Na região oeste da Amazônia, especificamente no estado do Acre, Brasil, o bambu nativo (Guadua weberbaueri Pilg.) cresce em grande abundância, o que chama atenção para uma possível exploração sustentável. A anatomia do bambu está relacionada às características físico-mecânicas, importantes propriedades relacionadas ao uso do bambu. Assim, este projeto tem como objetivo realizar a caracterização anatômica dos colmos, folhas e raízes de G. weberbaueri em diferentes ambientes que podem influenciar a anatomia, tais como dentro e ao longo da borda de uma floresta. Para a análise, foram colhidas amostras de colmos, folhas e raízes no Parque Zoobotânico da Universidade Federal do Acre, e lâminas permanentes foram visualizadas por microscopia óptica. Observamos que os feixes vasculares das nervuras centrais das folhas eram mais largos na borda da floresta do que dentro da floresta. Por outro lado, o estudo da anatomia das raízes mostrou diferenças nas medidas de raio dos elementos dos vasos do xilema, que eram maiores naqueles dentro da floresta do que na borda da floresta. Os feixes vasculares de colmos não apresentaram diferença, porém uma nova característica encontrada nessa espécie foi descrita (fibras condensadas em torno dos feixes) que pode ser utilizada para identificação. De maneira geral, foi observado que os diferentes ambientes podem determinar o tamanho dos elementos condutores em raiz e folha, embora não observamos essa influência nos colmos de $G$. weberbauri. 


\section{Introduction}

Given the predatory and wealth-concentrated development model on the agricultural frontier of the Amazonian States, which is based on the expansion of extensive cattle ranching since the 1970s, the Extractive Reserves and other Conservation Units appeared to be a part of the solution of the growing deforestation in the Amazon (Cunha 2001). This kind of conservation modality of the Brazilian environmental legislation simultaneously provides forest protection and sustainable use of natural resources as an alternative for production that is based on biodiversity and land tenure regularization. However, even this kind of protection is currently at risk.

According to Mognon et al. (2017), bamboo has good mechanical and physical characteristics because its stem has woody tissue, giving it potential as a wood substitute, in addition to helping with the reduction of forest degradation and having the capacity for carbon sequestration. In general, bamboo is seen as a renewable natural resource, and it is used in a sustainable development model with low production cost and great economic, social and environmental importance (Afonso 2011). However, the use and research of bamboo culture, although ancient, is mostly restricted to eastern countries, such as India, China and Indonesia, where most bamboo species are found (Lobovikov 2007; Troya and $\mathrm{Xu} 2014$ ).

In Brazil, the occurrence of native bamboo is concentrated in the southwestern region of the Amazon, where $38 \%$ of the forests are composed of various woody bamboo species, such as Guadua weberbaueri, G. sarcocarpa, Elytrostachys spp. and Arthrostylidium spp. (Judziewicz et al. 1999). In this region, there are native bamboos making up an area of approximately 16.15 million hectares of forest, including the states of Acre and southern Amazonas (Brazil), and the neighboring regions of Bolivia and Peru, which is considered the largest area of native bamboos in the world (Carvalho et al. 2013).

Brazil has a great diversity of bamboos, with approximately 18 genera, six of which are endemic, and 160 species, 129 of which are endemic (Judziewicz et al. 1999). Bamboo is a raw material that has enormous economic potential due to its large-scale occurrence and its multiple possibilities of use, such as housing, crafts, pulp, paper, panels, boards, veneer, flooring, roofing, fabrics, oil, gas and charcoal (Lobovikov 2007). The great diversity of species is demonstrated by plants divided between rhizomes and thatched systems (Nogueira 2013), and its morphological and anatomical characteristics are used in the identification of bamboos (Grosser and Liese 1971; Londoño and Davidse 1991; Liese 1998; Londoño and Ruiz-Sanchez 2014). Such differences found in the structure of the vascular bundles of the culms have allowed for the differentiation between genera and species (Grosser and Liese 1971; Liese 1998).

In the Amazon forest, bamboo species are distributed in two tribes, Bambuseae and Olyreae, with the genus Pariana being representative of the Olyreae tribe and the genus Guadua belonging to the Bambuseae tribe. The genus Guadua constitutes the "tabocais", as they are popularly known, which are woody, can reach 30 meters in height and $15 \mathrm{~cm}$ in diameter and differ from the others by the presence of ramified thorns in the nodes (Olivier and Poncy 2009; Filgueiras and Viana 2017).

According to Carmo et al. (2017), open forests with bamboo contribute significantly to the forest formation in the state of Acre, since they indentify eleven typologies in the state and eight of them possessing bamboo structures, with an average of 2,060 culms per hectare and diameters of $4.8 \mathrm{~cm}$, given an estimative of $29.559 \mathrm{~kg}$ per hectare, the genus Guadua is predominant. However, even though this bamboo forest has a density that allows a high potential for exploitation, its conversion to other uses is still restricted by a lack of both economic interest and research. The utilization of bamboo for various purposes is directed by its properties, as an example, the size of the fibrovascular bundles of Bambusa bambos has an influence in basic density (Santhoshkumar and Bhat 2014) and high density bamboos are required for some utilization, like charcoal (Shenxue 2004). Since physical and anatomical properties ultimately influence the utilization of bamboo resources, this makes the present study important to technological works.

Different growth environments may modify bamboo morphology and anatomy like observed by Cao (2001) and Yang et al. (2014). Considering that information on both anatomical and morphological features is essential for bamboo characterization, it is important to determine conservative characteristics with least influence by environment making them descriptors for identification (Pande 2008).

Thus, the overall objective of this work was to perform the anatomical characterization of $G$. weberbaueri Pilg. culms, leaves and roots in different growing environments, such as the interior and border of a forest.

\section{Material and Methods \\ Plant material}

Leaf and root materials were collected at the border and interior of the Zoobotanical Park forest. Eight leaves were collected, with four collected at the border and four collected inside of the forest (Figure 1). The mature leaves were collected in the first ramification of the culms (approximately 4 meters in height). The sampling of the collected roots followed the same method as that of the leaves, 
with a total of 8 roots, divided into collections of 4 roots at the border and 4 roots in the interior. The roots were collected near to the base of the culms.

The culms were also collected at the border and inside the forest of the Zoobotanical Park. A total of 8 culms were collected, with 4 collected at the border and 4 collected inside (Fig. 1). Culms of Guadua weberbaueri Pilg. that presented circumferences at height breast $(1.30 \mathrm{~m})$ varying between 10-14 cm were used and were chosen according to their physical-mechanical characteristics, such as stem length (approximately 5 meters), stem diameter $(3-4.5 \mathrm{~cm})$ and wall thickness $(1-2 \mathrm{~cm})$. Bamboos were selected by signs of stains and branches, which are fundamental parameters for determining the adult stage of bamboo (Silva 2020). A machete was used to harvest the culms. The base of bamboo culms were collected to make samples with dimensions of $2 \mathrm{~cm} \times 2 \mathrm{~cm}$.
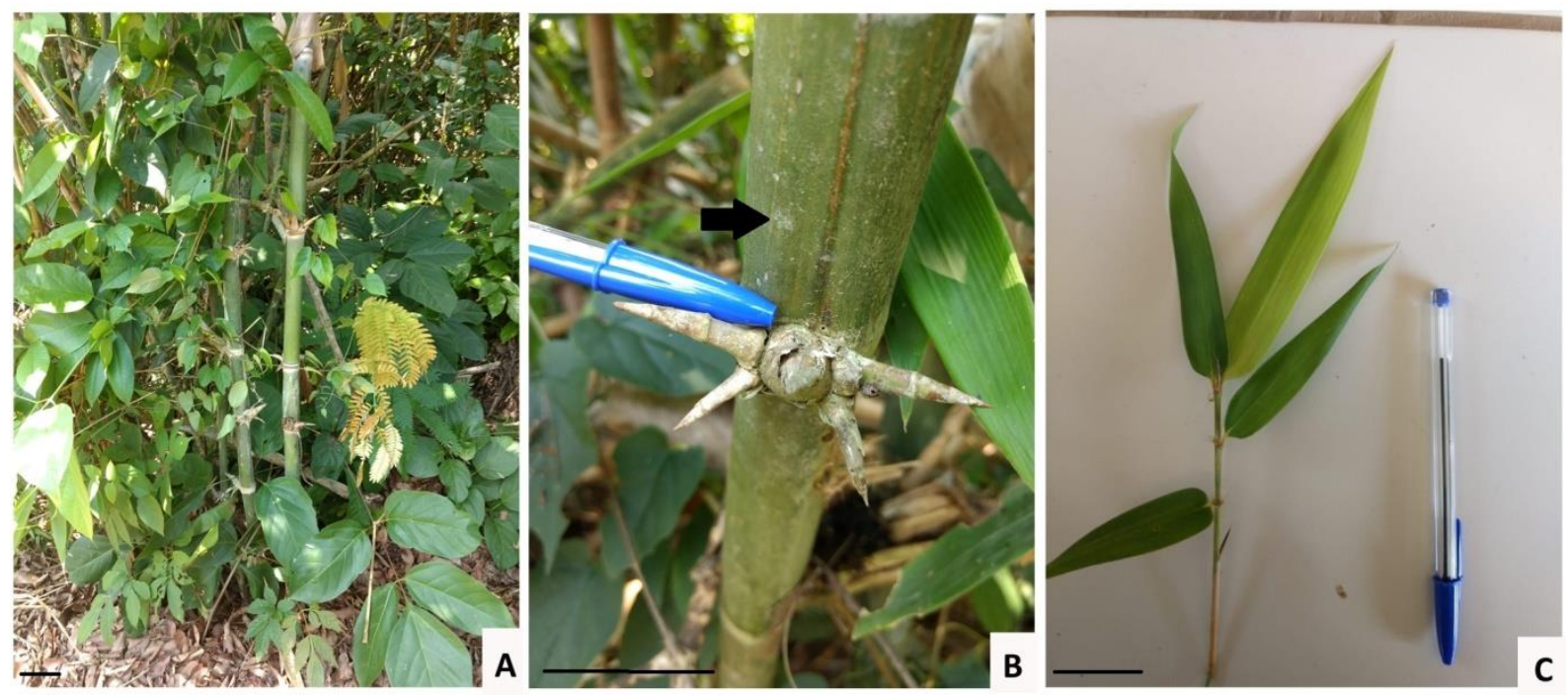

Figure 1. (A) Culms of Guadua weberbaueri at the forest border. Bar $=6 \mathrm{~cm}$. (B) Details of the culm thorns and node. The black arrow indicates a sign of stain as a parameter of bamboos selection. (C) Leaves of Guadua weberbaueri. $\mathrm{B}$ and $\mathrm{C}$ bars $=3 \mathrm{~cm}$.

\section{Section preparation}

Leaf samples and root samples were stored in tubes containing $40 \mathrm{ml}$ of Carnoy's fixative solution (alcohol and acetic acid) in a $3: 1$ (v/v) ratio, according to Kerk et al. (2003). After fixation of the materials, permanent microscope slides were prepared according to the following steps.

Fixation and infiltration: firstly, the samples were fixed in formaldehyde, acetic acid and $70 \%(\mathrm{v} / \mathrm{v})$ ethanol at a 1:1:18 (v/v) ratio (FAA 70, Johansen 1940), for $48 \mathrm{~h}$ (under vacuum for the first hour), and later preserved in $70 \%$ ethyl alcohol (v/v). Subsequently, samples were then dehydrated in an increasing ethanol series $[70-100 \%(\mathrm{v} / \mathrm{v})]$, for one hour each (under vacuum), infiltrated and embedded in historesin (Leica Heidelberg, Germany), following manufacturer's recommendations.

Assembly of the blocks: To cut the material in the microtome, it was necessary to join the infiltrated material with a small wooden block that served as a support in the microtome. This union was made with instant glue.

Microtome sectioning: The microtome (rotating microtome Leica®, RM212RT) was loaned by the Tissue Culture Laboratory of Universidade Federal do Acre (UFAC) and was used to create slides of leaves and roots with a thickness of 5 micrometers which were distended over water and adhered to microscopic slides in a plate heated to 40 ${ }^{\circ} \mathrm{C}$.

Staining: The toluidine blue $(0.5 \%)$ stain was used. To perform staining on the permanent sections of the infiltrated material, it was necessary to leave the sections in a container of toluidine blue for approximately 2 minutes. After this period, the sections were washed in water and dried. Entellan ${ }^{\circledR}$ (Merck) was used to cover the coverslip.

For the bamboo culms, the samples were softened under a pressure of $1 \mathrm{~atm}$ in an autoclave for 45 minutes before sectioning. Then, the sectioned samples were stored in vials containing $70 \%$ alcohol until the time of microtome cutting. The samples were prepared in the Wood Anatomy Laboratory of Fundação de Tecnologia do Estado do Acre (FUNTAC) a Technology Foundation. The permanent slides were prepared according to the following protocol.

Microtome sectioning: The microtome (Leica SM 2010R) was used for the sectioning of samples to a thickness of 20-40 micrometers.

Staining: The samples were discolored in sodium hypochlorite and then rinsed under running water. The staining method using Safranin basic red 2 (Êxodo Científica - CAS [477-73-6] C.I 50240) was adopted. To perform the staining, it was necessary to leave the slides in a cuvette containing safranin for approximately 2 minutes. 
Washing: To remove excess staining, 50\%, $70 \%, 96 \%$ and $100 \%$ alcohol was used to wash the samples. After drying with filter paper, the material was fixed with xylol and Entellan ${ }^{\circledR}$ (Merck) was used to cover the coverslip.

\section{Microscope observation and data analysis}

The observation of the slides and the photographic recording of the images were performed by using a microscope (LAS EZ from Leica Microsystems version 3.4) with a built-in camera.

For each plant tissue, the following variables were analyzed:

Roots: xylem vessels radius and frequency.

Leaves: radius of vascular bundles (central venation and parallel venations).

Culms: radius of vascular bundles (close to outer epidermis and to the inner of culms).

The measurements were carried out by using the software T Capture, and the statistical analyses of the averages were performed by using the $\mathrm{R}$ software (Rstudio interface).

\section{Results and Discussion}

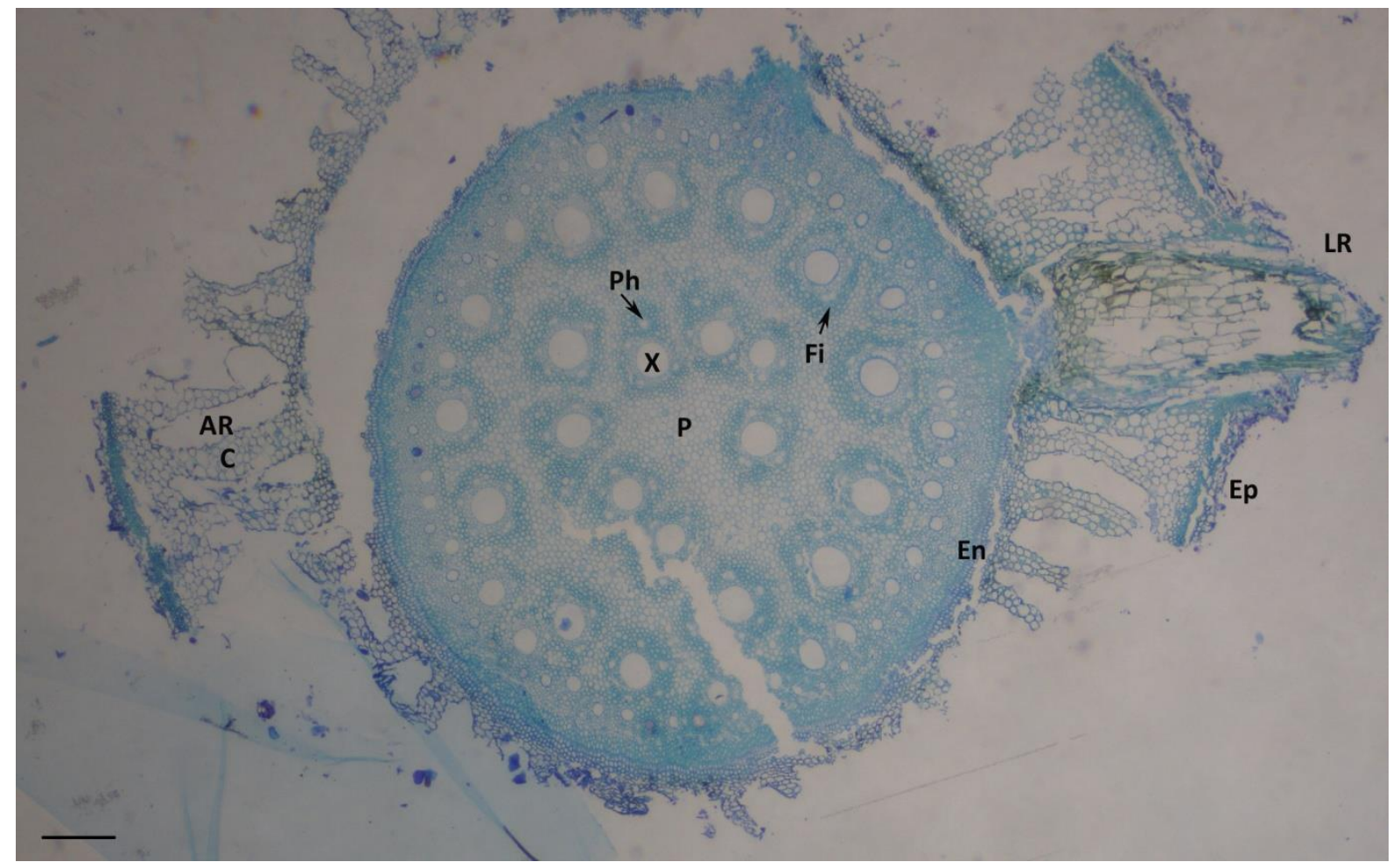

Figure 2. Cross section of a root (border of forest) fixed in Carnoy's solution. AR: aerenchyma; C: cortex; X: xylem; Ph: phloem; P: parenchyma; Fi: fibers; En: endoderm; LR: lateral root; Ep: epidermis. Note that the phloem cells are located around the xylem vessels as indicated by $\mathrm{Ph}$ and the arrow. The parenchyma is composed of lighter-colored cells, while fibers are darker colored and surround the xylem and phloem. Bar $=200 \mu \mathrm{m}$.

As described by Raechal and Curtis (1990) and Luis et al. (2017), we can observe the following in the anatomy of the root vascular cylinder: parenchyma, endodermis, vascular bundles (xylem
A comparative study of the root anatomy showed differences in the size of the xylem vessel elements. In order to determine differences in xylem sizes, the focus of the root study was on the inner part of the vascular cylinder (Figure 2). Carnoy's solution was adequate to preserve vascular cylinder, however, for fixation and storage, this method is not the most appropriated for future studies aiming the root cortex.

The roots had vessel measurement radius that ranged from very small to large $(11 \mu \mathrm{m}$ to $86 \mu \mathrm{m})$ among those found at the border of the forest. We also observed high variation $(12 \mu \mathrm{m}$ to $131 \mu \mathrm{m})$ among those from the interior of forest. The vessels observed in the $G$. weberbaueri root were visible under a 4-x magnifying objective lens, and visually they became more numerous and smaller when closer to the endoderm (Figure 2 and Figure3).

The average frequency of vessels per $\mathrm{mm}^{2}$ ranged from 12 vessels per $\mathrm{mm}^{2}$ in the interior to 17.5 vessels per $\mathrm{mm}^{2}$ in the forest border (Table 1 ). The measurements of the radius of root vessels greater than $50 \mu \mathrm{m}$ were analyzed and showed significant differences (Table 1). and phloem) and fibers surrounding bundles. In present study, the mean radius of the root vessels from border area was lower than the average radius of the vessels evaluated in the interior area. Plants 
can respond to water deficit situations by making physiological adaptive changes, emphasizing that

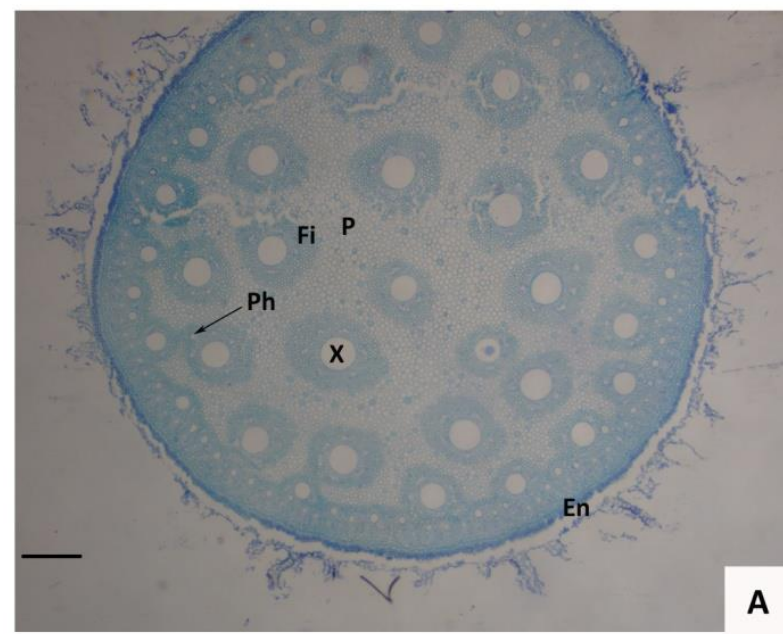

species that are in dry environments may present narrower vessels (Melo et al. 2007).

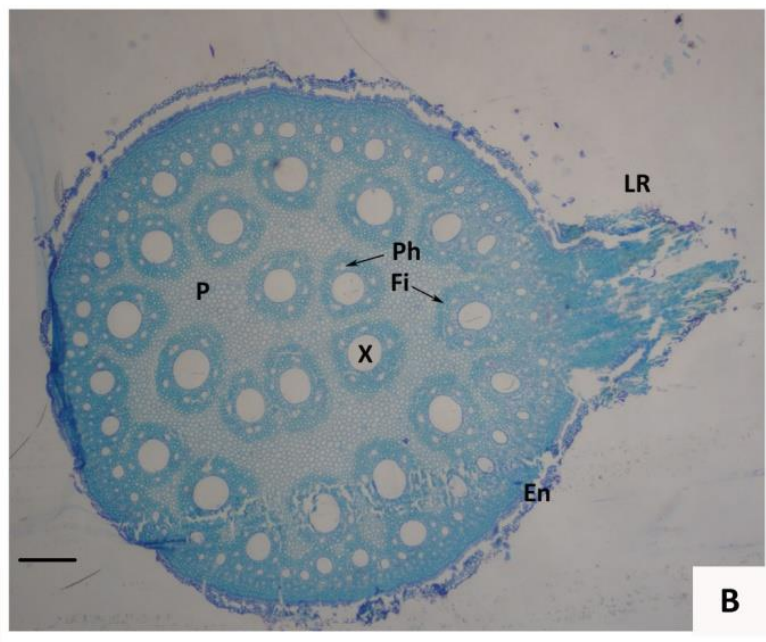

Figure 3. Anatomical characteristics of the root vascular cylinder of Guadua weberbaueri. (A) Vascular cylinder of bamboo roots at the border of forest. (B) Vascular cylinder of bamboo roots at the interior of forest. LR: lateral root; Ph: phloem; En: endoderm; Fi: fibers; X: xylem; P: parenchyma. Bar $=200 \mu \mathrm{m}$.

Table 1. Radius and frequency comparison of vascular elements of Guadua weberbaueri roots.

\begin{tabular}{lll}
\hline Forest location & Frequency & Radius $(\boldsymbol{\mu m})$ \\
\hline Border & $17.5 \mathrm{a}$ & $64.76 \mathrm{~b}$ \\
Interior & $12 \mathrm{~b}$ & $86.53 \mathrm{a}$ \\
CV $(\%)$ & 8.3 & 10.76 \\
\hline
\end{tabular}

Different letters following the numbers in the same column indicate that the means are significantly different based on the Tukey test at 5\% significance. CV $(\%)=$ coefficient of variance in percentage.

Christman (2011) observed that large vessels in Quercus gambelii experience high probability of cavitations. In our study of root anatomy, we showed differences in the radius measurements of the xylem vessel elements, which were larger inside the forest than in the border of forest. This reduction in the border area may be related to the adaptation of plants to avoid xylem air-seeding caused by low water availability where there is less vegetation and less soil moisture.

Curiously the frequency of root vessels was higher in the border of the forest than inside (17.5 and 12 , respectively), showing that the increase of vessels frequency is related to the border effect where the sunlight is more available and reflects in plant growth. This also may be related to increase of vascular bundles of central venation in the leaves (Figure 4). When they are concerned, the vascular bundles of the central venation presented an average of $88 \mu \mathrm{m}$ for the radius, which was higher than the average values of the interior forest vascular bundles radius $(63 \mu \mathrm{m}$; Table 2$)$. This difference possibly occurs due to the influence of the high light incidence in the border and low competition among plants (Mantuano et al. 2006). In the border area, there is a higher light rate which may cause greater development in bamboo species due to the increase in photosynthetic activities. This was found by Moreira et al. (2013) when analyzing Merostachys multiramea (a species of Bambuseae), in which greater development was observed in border areas influenced by light factors.

The leaf anatomy showed the presence of central vascular bundles with relatively larger radius compared to adjacent bundles, which was similar to the characterization performed by Jesus Junior et al. (2012) for Parodiolyra micrantha and $P$. ramosissima, which belong to the Olyreae tribe. Although G. weberbaueri belongs to the Bambuseae tribe, these species showed some similarity regarding the arrangement of their vascular bundles. Regarding the radius measurements of parallel bundles, there were no differences between the means, which were statistically equal inside the forest and in the border of forest (with radius averages of $25.6 \mu \mathrm{m}$ and $28.5 \mu \mathrm{m}$, respectively).

In addition, our work shows bulliform cells located only on the adaxial face of bamboo leaves which was in accordance to Vieira et al. (2002) and Luis et al. (2017). 


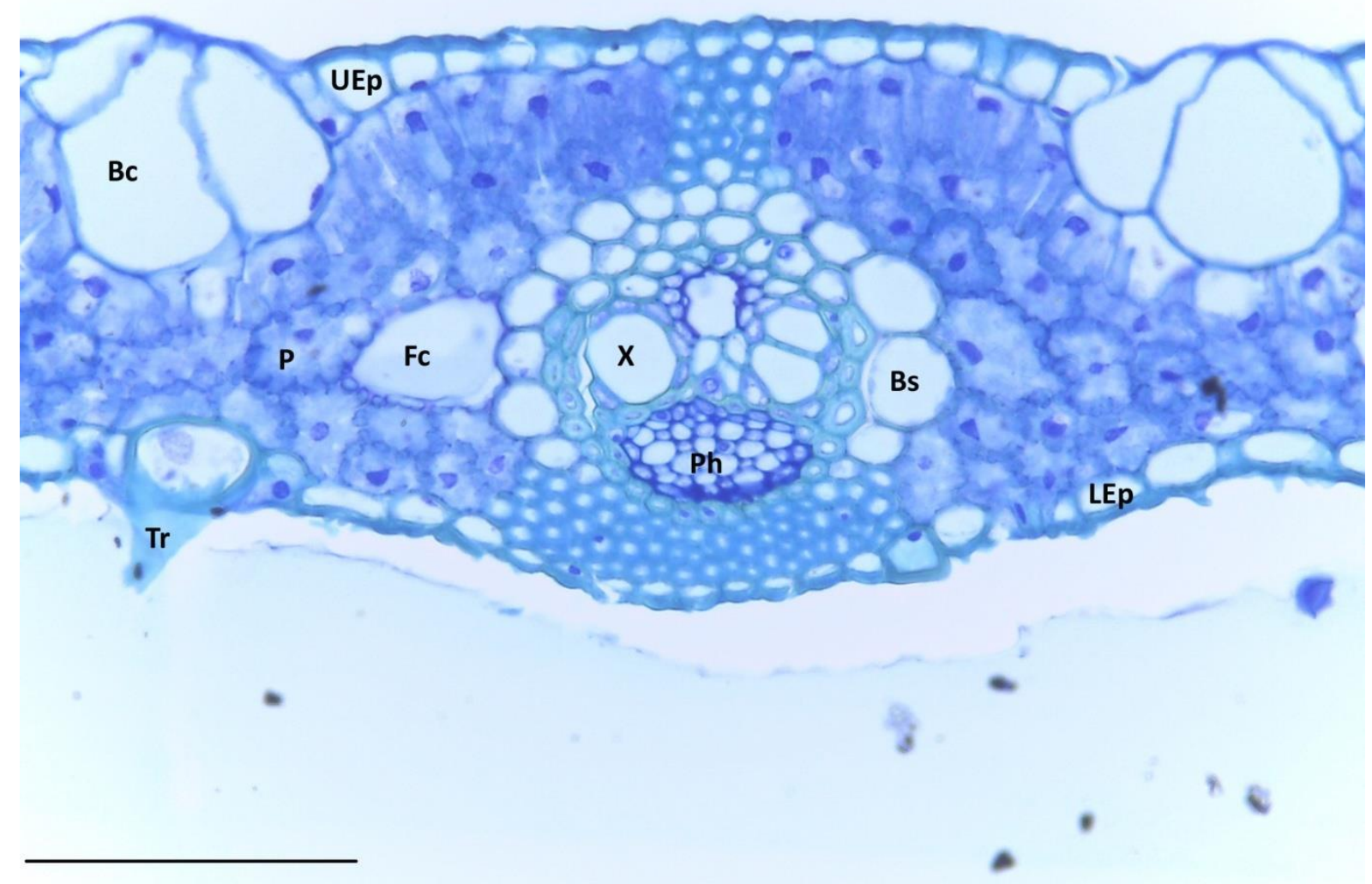

Figure 4. Cross section of a Guadua weberbaueri leaf blade. Visualization of the central vascular bundles. X: xylem; Ph: phloem; Bc: bulliform cell; Fc: fusoid cell; P: parenchyma; Bs: bundle sheath; UEp: upper epidermis; LEp: lower epidermis; Tr: trichomes. Bar $=150 \mu \mathrm{m}$.

Table 2. Comparison of the radius $(\mu \mathrm{m})$ of the vascular bundles of Guadua weberbaueri leaves.

\begin{tabular}{lll}
\hline Forest location & Central venation & Parallel venation \\
\hline Border & $88 \mathrm{a}$ & $28.5 \mathrm{~ns}$ \\
Interior & $63 \mathrm{~b}$ & $25.6 \mathrm{~ns}$ \\
$\mathrm{CV}(\%)$ & 1.53 & 5.34 \\
\hline
\end{tabular}

Different letters following the numbers in the same column indicate that the means are significantly different based on the Tukey test at 5\% significance. $\mathrm{CV}(\%)=$ coefficient of variance in percentage. $\mathrm{ns}=$ no significant difference.

For the descriptive study of the culms anatomy, the vascular system was observed, and it was found to be organized in collateral bundles consisting of two large metaxylem vessels, a protoxylem element, phloem and surrounding fibers (Figure 5).

The vascular bundles (average radius of $488.11 \mu \mathrm{m}$ ) observed in the culms of G. weberbaueri are visible under an objective lens with a $4 x$ magnification, becoming smaller as they approach the outer epidermis (average radius of $389.83 \mu \mathrm{m}$; coefficient of variation $9.77 \%$ ).

Three main vessel elements were observed in the vascular bundle and around the fibers, the filling consisted of parenchyma. The phloem (which faces the outer epidermis) was observed between the metaxylem vessel elements. Regarding the statistics performed to compare both environments, no significant differences were found (averages of $429.25 \mu \mathrm{m}$ at the border of the forest and $455.16 \mu \mathrm{m}$ inside the forest).

As described by Liese (1998) and Greco et al. (2011), parenchymal cells participate in storage and mobilization of energetic compounds to produce lateral shoots, inflorescences and seeds. In our work, we also observed that parenchyma occupies great part of G. weberbauri culms and therefore it could play an important function of carbohydrates maintenance for growth.

Metaxylem vessels are larger than protoxylem vessels and are separated by intercellular spaces and surrounded by cells with cellulosic or lignified walls, as found in Grosser and Liese (1971) and Liese (1998). The phloem is formed by sieved tube elements and companion cells and is located externally to the xylem facing the epidermis 
(Grosser and Liese, 1971). Liese (1985) describes that vascular bundles vary in their cellular composition, tissue organization, shape, size, number and distribution, as well as the type of sheath that surrounds them along the culm.

According to Grosser and Liese (1971) and Liese (1998), the vascular bundles of bamboos culms can be classified into four types: type I is observed in species of the genera Arundinaria and Phyllostachys; type II is observed in Melocanna, Cephalostachyum, Schizostachyum and Teinostachyum; type III is observed in
Oxytenanthera, Bambusa, Dendrocalamus, Gigantochloa and Thyrsostachys; and type IV is observed in Bambusa, Dendrocalamus, Gigantochloa and Thyrsostachys. In our report, we observed a fifth type of vascular bundle that has its fibers more condensed around the bundles when compared to those of the other bamboos with previously described anatomy. It would be interesting to study other species of Guadua in order to verify if type $\mathrm{V}$ is a characteristic of this genus or specific to Guadua weberbauri.

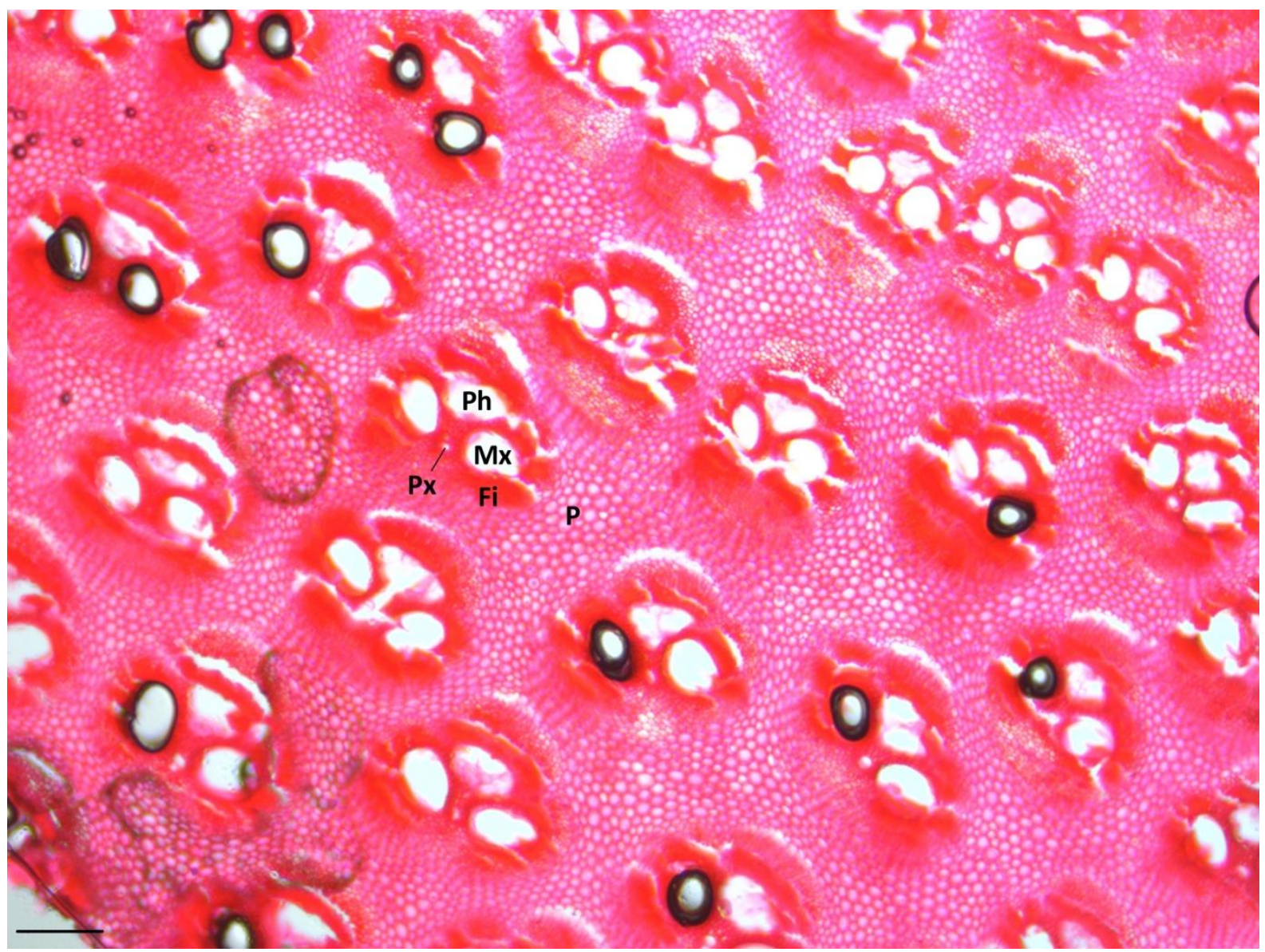

Figure 5. Anatomical structure of bamboo culms. Mx: metaxylem; P: parenchyma; Px: protoxylem; Ph: phloem; Fi: fibers. $B a r=400 \mu \mathrm{m}$.

\section{Conclusions}

The study of root anatomy showed differences in the radius measurements of the xylem vessel elements, which were larger inside the forest than in the border of forest. This reduction may be related to the adaptation of plants to lower water availability in the border area where there is less vegetation and less soil moisture. Interestingly, the frequency of vessels was higher in the border than inside the forest, which could be related to the growth. As in the leaf limb anatomy, which showed a difference when comparing the vascular bundles of the central venation, the bundles were larger in the border area than inside the forest, possibly due to the influence of the high light incidence.
In the descriptive study of the culm anatomy, the vascular bundle of Guadua weberbaueri presents condensed fibers surrounding the bundles, a different way of distribution when compared to other bamboos species. However, when the size is concerned, no differences were found between the border and the interior of the forest. The size and distributions of fibers around vascular bundles in the culms may be used for identification purposes.

\section{Acknowledgements}

We are thankful to André Gomes of FUNTAC (Technology Foundation of Acre State) to provide access of Woody Anatomy Laboratory. 


\section{References}

Afonso DG (2011) Bambu nativo (Guadua spp.): alternativa de desenvolvimento econômico $e$ sustentável para o estado do Acre. Dissertation, Universidade Federal do Paraná, 49 p.

Cao KF (2001) Morphology and growth of deciduous and evergreen broadleaved saplings under different light conditions in a Chinese beech forest with dense bamboo undergrowth. Ecology Research, 16(3): 509-517.

Carmo LFZ, Amaral EF, Bardales NG (2017) Ocorrência, biomassa, perdas e exploração de bambu em florestas da Amazônia no Acre, Brasil. In: Drumond PM, Wiedman G (Eds), Bambus no Brasil: da Biologia à Tecnologia. Rio de Janeiro: Instituto Ciência Hoje. p. 145-160.

Carvalho ALD, Nelson BW, Bianchini MC, Plagnol D, Kuplich TM, Daly DC (2013) Bamboodominated forests of the southwest Amazon: detection, spatial extent, life cycle length and flowering waves. PLOS ONE, 8: e54852.

Christman MA, Sperry JS, Smith DD (2012) Rare pits, large vessels, and extreme vulnerability to cavitation in a ring-porous tree species. New Phytologist, 193: 713-720.

Cunha LH (2001) Reservas extrativistas: uma alternativa de produção e conservação da biodiversidade. Vale do Ribeira: Encontro dos Povos do Vale do Ribeira. 37 p.

Filgueiras TS, Viana PL (2017) Bambus brasileiros: morfologia, taxonomia, distribuição e conservação. In: Drumond PM; Wiedman G (Eds), Bambus no Brasil: da Biologia à Tecnologia. Rio de Janeiro: Instituto Ciência Hoje. p. 10-27.

Greco TM, Pinto MM, Tombolato AFC (2011) Diversity of bamboo in Brazil. Journal Tropical Subtropical Botany, 23: 1-16.

Grosser D, Liese W (1971) On the anatomy of Asian bamboos, with special reference to their vascular bundles. Wood Science and Technology, 5: 290-312.

Jesus Junior LA, Oliveira RP, Leite KRB, Silva LB (2012) Comparative analysis of the leaf anatomy in two Parodiolyra species (Poaceae: Olyreae) occurring on forests in Eastern Brazil. Brazilian Journal of Biology, 72: 205-210.

Johansen DA (1940) Plant Microtechnique. London: McGraw-Hill Book Company. 523 p.
Judziewicz EJ, Clark LG, Londoño X, Stern MJ (1999) American bamboos. Washington: Smithsonian Institution Press, 392 p.

Kerk NM, Cesarani T, Tausta SL, Sussex IM, Nelson TM (2003) Laser capture microdissection of cells from plant tissues. Plant Physiology, 35: 132-27.

Liese W (1985) Anatomy and properties of bamboo. In: International bamboo workshop, Beijing, p. 196208.

Liese W (1998) The anatomy of bamboo culms. Beijing: International Network for Bamboo and Rattan. 208 p.

Lobovikov M, Paudel S, Piazza M, Ren H, Wu JQ (2007) World Bamboo Resources: A thematic study prepared in the framework of the Global Forest Resources Assessment 2005. Rome: FAO. 73 p.

Londoño X, Davidse G (1991) A new species of Guadua, G. ciliata (Poaceae: Bambusoideae), from Venezuela and Brazil. Novon, 1: 21-26.

Londoño X, Ruiz-Sanchez E (2014) Guadua tuxtlensis (Poaceae: Bambusoideae: Bambuseae: Guaduinae) una nueva especie inadvertida de la Región de Los Tuxtlas, Veracruz, México. Botanical Sciences, 92: 481-488.

Luis ZGL, Nogueira JS, Ribeiro DG, ScherwinskiPereira JE (2017) Caracterização anatômica dos órgãos vegetativos de bambu (Poaceae, Bambusoideae). In: Drumond PM, Wiedman G (Eds), Bambus no Brasil: da Biologia à Tecnologia. Rio de Janeiro: Instituto Ciência Hoje. p. 42-59.

Mantuano DG, Barros CF, Scarano FR (2006) Leaf anatomy variation within and between three "restinga" populations of Erythroxylum ovalifolium Peyr: (Erythroxylaceae) in Southeast Brazil. Brazilian Journal of Botany, 29(2): 209-215.

Melo HC, Castro EM, Soares AM, Melo LA, Alves JD (2007) Alterações anatômicas e fisiológicas em Setaria anceps Stapf ex Massey e Paspalum paniculatum L. sob condições de déficit hídrico. Hoehnea, 34: 145-153.

Mognon F, Sanquetta CR, Corte APD (2017) Bambu, uma alternativa para o sequestro de carbono. In: Drumond PM, Wiedman G (Eds), Bambus no Brasil: da Biologia à Tecnologia. Rio de Janeiro: Instituto Ciência Hoje. p. 227-239.

Moreira K, Smaniotto L, Santos MPV, Budke JC (2013) Maior abertura de dossel facilita o desenvolvimento de Merostachys multiramea Hack 
em uma floresta subtropical alto montana. Perspectiva, 37: 57-85.

Nogueira CL (2013) Ciência do material bambu e tecnologia de sua aplicação em vigas laminadas de seção transversal composta. Thesis, "Escola Superior de Agricultura de Queiróz”, Universidade de São Paulo. 167 p.

Olivier J, Poncy O (2009) A taxonomical revision of Guadua weberbaueri Pilg. and Guadua sarcocarpa Londoño \& P. M. Peterson (Poaceae). Candollea, 64: 171-178.

Pande PK (2008) Anatomy of Indian Bamboos. ENVIS: Centre on Forestry. p. 109-130.

Raechal LJ, Curtis JD (1990) Root Anatomy of the Bambusoideae (Poaceae). American Journal of Botany, 77: 475-482.

Santhoshkumar R, Bhat KV (2014) Variation in density and its relation to anatomical properties in bamboo culms, Bambusa bambos (L.) Voss. Journal of Plant Sciences, 2(3): 108-112.

Shenxue J (2004) Training Manual of Bamboo Charcoal for Producers and Consumers. Nanjing China: Bamboo Engineering Research Centre. 54 p.

Yang SJ, Sun M, Zhang YJ, Cochard H, Cao KF (2014) Strong leaf morphological, anatomical, and physiological responses of a subtropical woody bamboo (Sinarundinaria nitida) to contrasting light environments. Plant Ecology 215: 97-109.

Silva MC (2020) Dinâmica do bambu (Guadua weberbaueri Pilger. Poaceae) em função da sazonalidade climática no leste do acre. Dissertation, Universidade Federal do Acre. 70p.

Troya MFA, Xu C (2014) Plantation management and bamboo resource economics in China. Ciencia y Tecnologia, 7: 1-12.

Vieira RC, Gomes DMS, Sarahyba LS, Arruda RCO (2002) Leaf anatomy of three herbaceous bamboo species. Brazilian Journal of Biology, 62: 907-922. 